Jurnal Sewaka Bhakti Lembaga Penelitian dan Pengabdian Kepada Masyarakat

Universitas Hindu Indonesia Denpasar

Volume 2, Nomor 1 April 2019

ISSN: 2654-2935 (Online)

https://ejournal.unhi.ac.id/index.php/sewakabhakti

pp. 82-90

\title{
PENYULUHAN TEKNIK PEMASARAN DAN PELATIHAN \\ PENYUSUNAN LAPORAN KEUANGAN PADA KELOMPOK HOME INDUSTRI KACANG KAPRI DI BANJAR DINAS PESANGKAN ANYAR KECAMATAN SELAT KARANGASEM
}

\author{
Oleh \\ I Wayan Sudiana, Ni Luh Adisti Abiyoga Wulandari, Kadek Dewi Padnyawati, I \\ Putu Deddy Samtika Putra, Ni Ketut Muliati \\ Fakultas Ekonomi Bisnis Dan Pariwisata Universitas Hindu Indonesia
}

\begin{abstract}
ABSTRAK
Desa Selat Duda berada di Kecamatan Selat Karangasem yang sebagian penduduknya dilihat dari segi mata pencaharian sebagian besar bekerja sebagai petani. Hasil perkebunan di Desa Duda mayoritas penghasil salak akan tetapi ada juga yang menghasilkan kacang tanah. Beberapa warga terutama para ibu wajib bekerja untuk memenuhi kebutuhan keluarga. Selain sebagai petani ada kelompok ibu rumah tangga bekerja membuat kacang kapri dengan memanfaatkan hasil kebun yang ada didaerahnya untuk menambah pundi-pundi penghasilan. Pembuatan Kacang Kapri ini masih dilakukan dengan cara tradisional. Mitra Home Industri Kacang Kapri ini dalam menjalankan bisnisnya belum menerapkan teknik pemasaran yang benar, cara memasarkan produknya dilakukan dengan menitipkan produknya di warung-warung dan sesuai dengan pesanan dan hal yang sama juga terjadi dalam penyusunan laporan keuangan yang belum ada penerapanya dalam menjalankan usaha ini sehingga belum bisa diketahui besarnya keuntungan dan kerugian yang dialami.Teknik pemasaran memiliki peranan yang sangat penting dalam menjalankan sebuah usaha karena kepuasan pelanggan merupakan tujuan akhir dalam teknik pemasaran, maka perlu untuk memahami dan mengerti mengenai manajemen pemasaran yang tepat. Laporan keuangan dalam sebuah usaha merupakan proses akhir dari proses akuntansi. Laporan ini berfungsi sebagai bahan informasi dan bahan pengambilan keputusan bagi para pemakai dalam menjalankan usahanya. Berdasarkan permasalahan ini maka kami memberikan pendampingan dan pelatihan Teknik Pemasaran dan Pelatihan Penyusunan Laporan Keuangan yang sederhana sehingga kedepanya usahanya bisa lebih maju dan bersaing ditengahtengan pesatnya pertumbuhan Ekonomi saat ini. Dengan pengabdian masyarakat ini diharapkan mitra Home Industri Kacang Kapri sudah mampu melaksanakan teknik pemasaran dengan baik dan juga dalam penyusunan laporan keuangan yang benar.
\end{abstract}

Kata Kunci : Penyuluhan, Pelatihan, Home Industri Kacang Kapri 


\section{Pendahuluan}

Kecamatan Selat adalah sebuat kecamatan di Kabupaten Karangasem dengan luasnya adalah $80,35 \mathrm{~km}^{2}$ dengan jumlah penduduk 34.760 jiwa pada tahun 2002. Perjalanan dari Denpasar menuju Banjar Dinas Pesangkan Anyar memerlukan waktu kurang lebih 180 menit. Kecamatan Selat juga terkenal dengan sebutan Desa Selat Duda, dari segi mata pencaharian sebagian besar bekerja sebagai petani. Daerah ini terkenal dengan sektor perkebunan salak dan ada juga yang menghasilkan kacang tanah. Beberapa warga terutama yang ibu-ibu wajib bekerja untuk memenuhi kebutuhan keluarga. Selain sebagai petani ada beberapa rumah tangga bekerja membuat kacang kapri untuk menambah penghasilanya.

Kacang kapri merupakan salah satu camilan yang cara pembuatanya masih tradisional, kacang kapri ini dibuat dari biji kacang pilihan yang cara pembuatan di rendam dengan air hangat terlebih dahulu dengan waktu yang kurang lebih 2 jam biar kulit halus dari kacang lebih mudah bersihkan, setelah itu baru kacang ditiriskan lalu di campurkan dengan bumbu biar rasanya gurih sebelum kemudian di goreng. Setelah itu kacang kapri di tiriskan terlebih dahulu biar kering dan kemudian di bungkus yang selanjutnya siap untuk dititipkan di warung-warung. Kacang kapri ini menjadi makanan favorit pada saat kumpul-kumpul bersama keluarga dan juga menjadi makanan pendamping pada saat ada acara-acara besar seperti acara nikahan, seminar, rapat dan acara yang lainya. Kacang kapri ini di produksi oleh satu kelompok Ibu Rumah Tangga di Banjar Dinas Pesangkan Anyar Karangasem, kacang kapri ini diproduksi sesuai dengan pesanan yang datang dan pemasaranya juga dilakukan dengan cara menitipkanya di warungwarung dan pasar yang ada di Banjar Dinas Pesangkan Anyar Karangasem. Harga produk berkisar Rp 1.000 kalo menjualnya ecer di warung-warung sedangkan kalo berdasarkan pesanan itu akan disesuikan lagi dengan pesananya. Mitra dalam kegiatan ini adalah kelompok Home industri yang. Dalam sebulan 
kacang kapri yang dihasilkan bervariasi sesuai dengan pesanan dari para pelanggan.

Hasil diskusi yang dilakukan dengan mitra kegiatan yaitu terbatasnya jenis kacang kapri yang di produksi karena keterbatasan wawasan, pemasaran produknya kurang luas jangkaunya disertai dengan belum dimanfaatkanya teknologi, disamping itu juga penyusunan laporan keuanganya masih tradisional sehingga pemasukan yang diterima kurang jelas. Permasalahan yang terjadi saat ini adalah belum mengetahui bagaimana caranya melakukan pemasaran yang tepat dan bagaimana cara penyusunan laporan keuangan yang tepat sehingga mereka dapat mengetahui secara pasti keuntungan dan kerugian yang diperoleh dalam menjalani usahanya. Hal ini dikarenakan mitra belum melakukan teknik pemasaran yang baik dan penyusunan laporan keuangan yang tepat terhadap modal yang di gunakan dalam menjalankan usahanya, yang mereka lakukan hanyalah membuat catatan sederhana pada saat ada pesanan saja. Mereka belum menerapkan strategi pemasaran dan penyusunan laporan keuangan dalam menjalankan usahanya sehingga mereka tidak bisa mengetahui berapa keuntungan dan kerugian yang di peroleh.

Teknik pemasaran dan penyusunan laporan keuangan masing-masing memiliki peranan yang sangat penting dalam menjalankan usahanya sehingga mampu menunjang proses bisnis yang dijalani, sehingga bisa mencapai hasil yang lebih baik bagi usaha kedepannya. Teknik pemasaran merupakan semua kegiatan perusahaan dalam perencanaan pemasaran dalam upaya mencapai kepuasan pelanggan sebagai tujuan perusahaan. Penyusunan laporan keuangan merupakan proses akhir dari sebuah peroses akuntansi dalam pengelolaan aktivitas keuangan dalam perusahaan, dimulai dari cara memperoleh modal dan mempergunakannya. Hasil yang maksimal akan diperoleh jika pengelolaan modal dilakukan secara efisien,efektif dan tepat sasaran sehingga tujuan perusahaan dapat tercapai sesuai rencana yang telah di tetapkan. 
Berdasarkan permasalahan yang dihadapi oleh mitra maka solusi yang bisa ditawarkan dalam pengabdian masyarakat ini adalah melakukan penyuluhan mengenai pentingnya teknik pemasaran dan pelatihan penyusunan laporan keuangan bagi usaha yang di jalankan oleh mitra. Langkah yang akan dilakukan adalah dengan cara memberikan penyuluhan teknik pemasaran dan pelatihan penyusunan laporan keuangan sehingga hasil yang ingin dicapai dalam pengabdian masyarakat ini adalah Kelompok Home Industri Kacang Kapri ini bisa mengelola teknik pemasaran dan penyusunan laporan keuangan dengan tepat dan baik. Berdasarkan observasi yang dilakukan pada Kelompok Home Industri Kacang Kapri di Banjar Dinas Pesangkan Anyar Karangasem belum menerapkan teknik pemasaran dan penyusunan laporan keuangan dalam menjalankan usahanya.

Tujuan dari pada program pengabdian masyarakat ini adalah mampu Memberikan pengetahuan dan pelatihan kepada Kelompok Home Industri Kacang Kapri yang berada di Banjar Dinas Pesangkan Anyar Kecamatan Selat Karangasem tentang manfaat daripada Teknik Pemasaran dan penyusunan laporan keuangan dalam menjalankan sebuah bisnis. Dengan pengetahuan teknik pemasaran dan pelatihan penyusunan laporan keuangan yang di miliki maka harapan kita kedepanya mereka akan mampu menghadapi banyaknya pesaing yang akan bermunculan dalam pesatnya pertumbuhan perekonomian di Indonesia.

\section{Metoda Pemecahan Masalah}

Metoda yang gunakan dalam pelaksanaan kegiatan pengabdian masyarakat ini adalah metode dengan cara memberikan penyuluhan teknik pemasaran dan pelatihan penyusunan pembukuan secara langsung kepada mitra Home Industri Kacang Kapri di Banjar Dinas Pesangkan Anyar Kecamatan Selat Karangasem, terdapat tiga bentuk kerja utama yang dimulai dari sosialissi kegiatan, varian rasa dan jumah produksi, kemasan yang lebih baik dengan peningakatn teknologi pemasaran dan penyusunan laporan keuangan. 


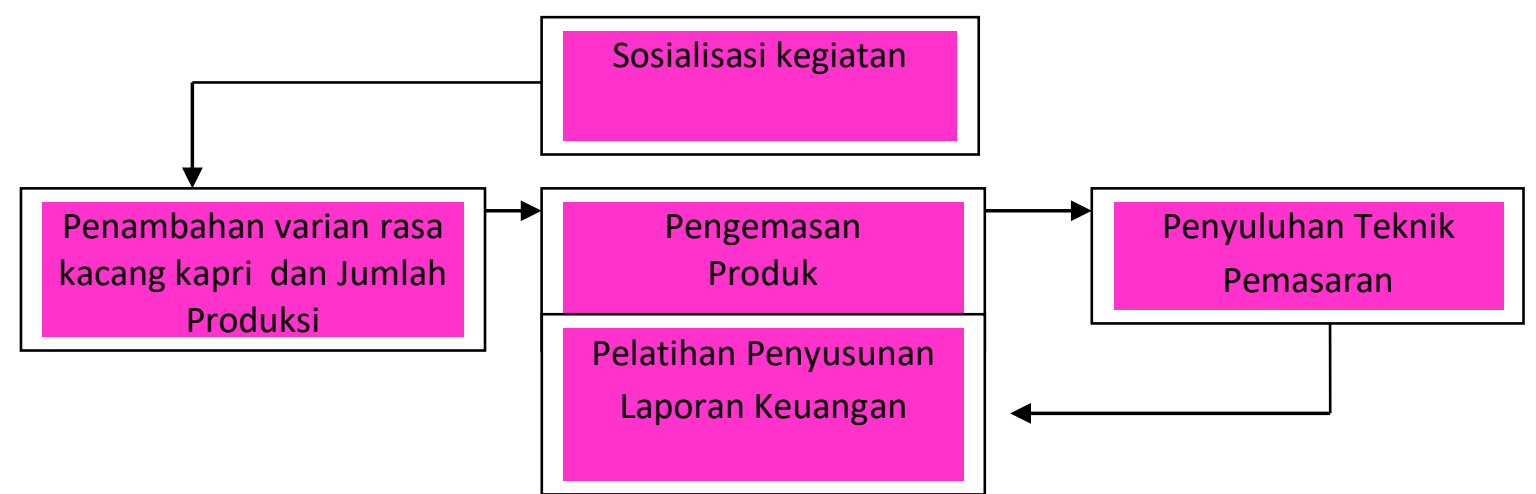

Gambar 1. Prosedur Kerja Pengabdian Masyarakat Kacang Kapri

Berdasarkan permasalahan mitra yang menjadi prioritas, maka ada beberapa kegiatan yang akan dilaksanakan untuk menangani permasalahan yang terjadi seperti :

1. Sosialisasi dilakukan dengan cara mengumpulkan peserta dalam sebuah diskusi. Pada sosialisasi ini akan dihadiri oleh narasumber yang akan menjelaskan mengenai pengembangan bisnis untuk industri kecil. Peserta yang hadir adalah mitra Kelompok Home Industri agar bisa bersama-sama mengembangkan bisnisnya.

2. Penambahan varian rasa kacang kapri dan jumlah produksi untuk meningkatkan pendapatan mitra berkisar 50\%-100\% atau setidaknya bisa membuat pendapatan mitra tetap stabil.

3. Penyuluhan teknik pemasaran dengan sistem pemasaran yang lebih baik dan memberikan pemaparan pengetahuan tentang teknik pemasaran dan juga memberikan penyuluhan dalam memasarkan produk yang dihasilkan agar tidak menunggu pesanan saja dari pelanggan

4. Memberikan pemaparan pengetahuan tentang penyusunan laporan keuangan dan praktek pelatihan penyusunan laporan keuangan.

\section{Hasil Dan Pembahasan}

Penyuluhan merupakan upaya yang diberikan untuk meningkatkan sumber daya manusia dari mitra melalui pemberian materi-materi yang 
disampaikan melalui penyuluhan antara lain : teknis pengemasan produk, teknis penambahan varian rasa dan jumlah produksi, teknis pemasaran dan teknis penyusunan laporan keuangan. Produk yang dihasikan mitra adalah kacang kapri dengan jenis produk yang banyak dan jumlah produksi yang meningkat serta pengemasan yang lebih baik dengan pemasaran yang sudah melalui sosial media dan penyusunan laporan keuangan yang memadai sehingga sudah bisa mengetahui berapa keuntungan yang sudah di peroleh dalam menjalankan usahanya.

Kegiatan penyuluhan teknis pengemasan produk, teknis penambahan varian rasa, jumlah produksi dan teknik pemasaran serta pelatihan penyusunan laporan keuangan pada Home Industri Kacang Kapri dilaksanakan di rumah Ibu I Gusti Ayu Oka yang beralamat di Banjar Dinas Pesangkan Anyar Kecamatan Selat Karangasem. Adapun susunan acara kegiatan adalah sebagai berikut :

Tabel 1 Susunan Acara Kegiatan

\begin{tabular}{|l|l|r|}
\hline \multicolumn{1}{|c|}{ No } & \multicolumn{1}{|c|}{ Kegiatan } & \multicolumn{1}{c|}{ Durasi } \\
\hline 1 & Pekenalan & 10 menit \\
\hline 2 & Indikator Pembelajaran & 10 Menit \\
\hline 3 & Pengenalan Teknik Pemasaran & 45 Menit \\
\hline 4 & Pelatihan Penyusunan Laporan Keuangan & 155 Menit \\
\hline 5 & Panutup & 10 Menit \\
\hline
\end{tabular}

Berikut ini merupakan uraian dari pelaksanaan kegiatan sesuai dengan susunan acara pengabdian yang telah dibuat:

1. Perkenalan

Pertemuan pertama kegiatan pengabdian masyarakat ini diawali dengan pengenalan kami sebagai pelaksana pengabdian dan pengenalan institusi Universitas Hindu Indonesia Denpasar

2. Indikator Pembelajaran 
Setelah memperkenalkan dan menjelaskan secara singkat tujuan dilaksanakan pengabdian, penulis sedikit menjelaskan tentang indikator pembelajaran yang akan dicapai, Indikator Pembelajaran seperti : Memahami pengertian pemasaran, manfaat pemasaran, memahami konsep teknik pemasaran, memahami pengertian penyusunan laporan keuangan, memahami fungsi penyusunan laporan keuangan dan konsep penyusunan laporan keuangan. Diharapkan mampu memasarkan produknya dengan lebih baik lagi dan mampu melakukan penyusunan laporan keuangan, dan membuat pencatatan keuangan yang sederhana

3. Pengenalan Teknik Pemasaran

Pada sesi ini dilakukan dengan memberikan pemaparan pengetahuan tentang pengertian pemasaran, fungsi pemasaran dan konsep pemasaran, sehingga dapat melakukan teknik-teknik pemasaran dengan baik. Diberikan juga bagaimana cara melakukan pengemasan produk yang menarik agar mampu bersaing di di pasaran yang lebih luas dan juga memberikan penyuluhan dalam memasarkan produk yang dihasilkan agar tidak menunggu pesanan saja dari pelanggan tetapi juga proaktif melakukan pemasaran melalui media sosial yang banyak tersedia saat ini.

4. Pengenalan Penyusunan Laporan Keuangan

Pada sesi ini akan diberikan pemahaman tentang pengertian, fungsi dan konsep penyusunan laporan keuangan bagi usaha kecil. Materi pemahaman tentang pentingnya penyususnan laporan keuangan bagi usaha kecil. Diharapkan mampu mengerti dan memahami dengan baik proses penyusunan laporan keuangan yang benar dan mampu membuat laporan keuangan yang sederhana dalan menjalankan usahanya sehingga kedepanya pengelolaan keuangan usahanya akan lebih baik. Diharapkan agar mitra dapat mengetahui keuntungan atau 
kerugian yang diperoleh setelah mendapatkan pelatihan penyusunan laporan keuangan ini.

5. Materi Pemahaman Neraca, Rugi Laba dan Buku Kas

Pada Sesi ini akan diberikan tentang pemahaman mengenai laporan Laba-Rugi, perubahan Modal dan Neraca Keuangan dan pelatihan pembuatan buku khas secara sederhana menggunakan buku kas manual tanpa aplikasi.

Setelah pelatihan, maka akan dilakukan evaluasi kegiatan pelatihan yaitu dengan teknik wawancara langsung dengan peserta pelatihan dimana dari hasil wawancara diperoleh hasil sebagai berikut:

1. Materi penyuluhan teknik pemasaran yang diberikan menarik dan mudah dipahami oleh peserta yang mengikuti penyuluhan.

2. Materi pelatihan penyusunan laporan keuangan yang diberikan cukup menarik dan cukup mudah dipahami dan dimengerti oleh peserta sehingga peserta merasa cukup puas dengan pelatihan ini.

3. Hasil dari pelatihan penyusunan laporan keuangan membantu peserta dalam menglola keuangan usaha yang dimiliki oleh peserta yang mengikuti pelatihan pelatihan.

4. Waktu pelaksanaan pelatihan cukup baik namun perlu diperpanjang lagi agar pemahaman materi lebih mendalam.

\section{Simpulan}

Adapun kesimpulan yang dapat diambil dari kegiatan pengabdian ini adalah sebagai berikut

1. Perseta pelatihan mampu menambah varian rasa dan jumlah produksi lebih banyak lagi sehingga lebih mudah memenuhi kebutuhan konsumen

2. Peserta pelatihan mampu melakukan pengemasan produk yang menarik sehingga membuat para pelanggan tetap menjadi pelanggan yang setia. 
Jurnal Sewaka Bhakti

Lembaga Penelitian dan Pengabdian Kepada Masyarakat

Universitas Hindu Indonesia Denpasar

Volume 2, Nomor 1 April 2019

ISSN: 2654-2935 (Online)

https://ejournal.unhi.ac.id/index.php/sewakabhakti

pp. $82-90$

3. Peserta pelatihan yaitu mitra Home Industri Kacang Kapri di Banjar Dinas Pesangkan Anyar Kecamatan Selat karangasem memperoleh pengetahuan tentang teknik pemasaran yang baik dan benar sehingga kedepanya mampu menjalankan usahanya lebih baik lagi.

4. Peserta pelatihan yaitu mitra Home Industri Kacang Kapri di Banjar Dinas Pesangkan Anyar Kecamatan Selat karangasem memperoleh pengetahuan tentang Penyusunan laporan keuangan yang tepat sehingga kedepanya mampu mengelola keuangan usahanya serta mampu membuat laporan keuangan sederhana.

\section{Saran}

Saran yang dapat diberikan dalam kegiatan pengabdian ini adalah dalam kegiatan pengabdian berikutnya, cakupan mitra lebih luas yaitu bukan hanya satu kelompok mitra tetapi satu desa mitra serta waktu pelatihan lebih diperpanjang agar pemahaman materi lebih dalam oleh peserta.

\section{Ucapan Terimakasih}

Ucapan terimakasih disampaikan kepada Rektor dan LPPM Universitas Hindu Indonesia Denpasar yang telah memfasilitasi sehingga kegiatan ini berjalan dengan baik dan memenuhi target luaran.

\section{Daftar Pustaka}

Agus, Sartono, 2002, Manajemen Keuangan : Teori dan Aplikasi, edisi keempat, cetakan pertama, penerbit : BPFE, Yogyakarta

Darsono, dan Ashari, 2005, Pedoman Praktis Memahami Laporan Keuangan, edisi pertama, Penerbit : Andi, Yogyakarta

Mangkunegara. 2005. Sumber Daya Manusia Perusahaan. Remaa Rosdakarya: Bandung

Philip Kotler.2006. Prinsip-prinsip Pemasaran. Erlangga : Ciracas Jakarta 